\title{
A EMERGÊNCIA DA ENTIDADE DON JUAN NA OBRA DE MILAN KUNDERA
}

${ }^{*}$ Wilton Barroso

${ }^{*}$ Maria Veralice Barroso

RESUMO: Este estudo tem por objetivo uma análise acerca do comportamento libertino ${ }^{1}$ dos don Juans ${ }^{2}$ kunderianos. De posse da compreensão do percurso dessa personagem na historiografia literária, objetiva-se uma comparação analítica dessa figura com as composições de Milan Kundera, tendo como centro de observação os seus universos objetivos e subjetivos de onde se acredita, emanam grandes temas vividos pela humanidade nos tempos atuais.

PALAVRAS-CHAVE: Donjuanismo; Pós-modernidade; Subjetividade.

ABSTRACT: This study aims an analysis of the behavior of some libertine kuderian Don Juans. Understanding the course of that character in literary history, the objective is to develop an analytical comparison of this figure with the compositions of Milan Kundera, having as an observation center their objective and subjective worlds, from where, it is believed, emanate major themes experienced by humanity in current times.

KEYWORDS: Donjuanism; Post-modernity; Subjectivity.

\footnotetext{
* Wilton Barroso é Doutor em Epistemologia pela Universidade de Paris VII. Professor do Departamento de Filosofia - FIL e do Programa de Pós-graduação em Literatura da Universidade de Brasília - PPGL - UnB.

** Maria Veralice Barroso é doutoranda em Teoria Literária pela Universidade de Brasília $-\mathrm{UnB}$

${ }^{1}$ No Império Romano, tratava-se por libertino um escravo alforriado, já no século XVII - no qual se insere don Juan: o mais clássico dos libertinos - recebia essa denominação aquele que se alforriava da moral e da religião.

${ }^{2}$ Optamos pela grafia don Juan, por ser assim escrita no texto original do espanhol Tirso de Molina.
} 


\section{INTRODUÇÃO}

Nascido na Tchecoslováquia, atual República Tcheca, e exilado na França, Milan Kundera apresenta ao universo da crítica literária uma obra ampla, parte escrita em língua eslava e outra parte escrita em língua francesa.

Composta por narrativas ficcionais (contos e romances) e por ensaios teóricos, a obra kunderiana é relevante enquanto fonte de inspiração e reflexão sobre o romance. A paixão pelo gênero se evidencia numa produção considerável de textos dessa natureza, bem como pelos ensaios nos quais - a partir de obras e autores que perfizeram a história e constituíramse enquanto tradição desse gênero narrativo - desenvolve reflexões significativas sobre a história do romance e da humanidade. As reflexões empreendidas por Milan Kundera nos textos teóricos resultam de uma lógica artística fundada na própria experiência enquanto romancista e enquanto testemunha das tensões que mudariam os valores humanos e estéticos instaurando uma nova ordem mundial.

As personagens de Milan Kundera sejam elas, homens ou mulheres, centrais ou secundárias, vitoriosas ou fracassadas, apresentam um comportamento que inicialmente, poderia ser definido como libertino, tal comportamento levou o próprio escritor, certa vez, a referir-se as suas criações como 
"atletas sexuais ${ }^{3 \text { ". }}$ Nesse sentido, procurar compreender a escrita romanesca de Milan Kundera exige do pesquisador uma postura crítica, associada a uma tentativa unificadora, diante da multiplicidade de conquistadores que transita no interior dela.

Assim, com base nas reflexões desse autor, neste trabalho, procuramos entender o texto literário enquanto um cenário em que o humano coexiste com a grande História. A literatura não é aqui, representação somente de fatos grandiosos é principalmente, representação do cotidiano do homem comum, suas crenças, seus sonhos, seus conflitos, seus hábitos; enfim, é uma expressão artística, que faz circular idéias e experiências, vivenciadas cotidianamente.

A relação homem/mundo, metaforicamente pensada nos possibilita um olhar sobre os aspectos internos e externos das experiências humanas. Assim sendo, procuramos olhar na produção romanesca kunderiana, em especial na sedução e no erotismo, aquilo que emana por meio de seus don juans. Esperamos atingir assim um espaço privilegiado de observação e reflexão acerca das questões que permeiam e circundam a existência nas últimas décadas do século passado.

De todo modo, ao se falar em don Juan é importante sempre situar a questão relevante para o teor dessa discussão: qual don Juan será objeto de atenção? Será aquele barroco, inserido numa perspecticiva ético-social, Ser atemporal, de caráter narcisista e coração de pedra? Ou quem sabe, será aquele conquistador de modos românticos, pautado nas questões estéticomorais, mais humanizado, aquele que seduz, mas na mesma proporção é seduzido?

A compreensão de tais questões parece ser relevante para a nossa análise, uma vez que, desde sua aparição no século XVII (1630 a 1635) ${ }^{4}$, a figura lendária de don Juan ressurgiu em várias épocas, línguas e culturas diferentes. Assumindo assim, muitas faces, mas que curiosamente se acredita pertencer a um único Ser.

Para unificar a personagem no decorrer de seu percurso na historiografia das artes e na literária, tomamos como ponto de referência o fundamento nela mais evidente e conseqüentemente, ou seja aquele que é o mais observado no curso de suas manifestações: a de sedutor.

\footnotetext{
${ }^{3}$ Referindo se a Rubens em A lentidão (1990), um dos don Juans kunderianos, o narrador diz: "...e acelerou os movimentos do amor,como um verdadeiro atleta do sexo..."

${ }^{4}$ A data exata de publicação da peça de Tirso de Molina varia, conforme a fonte pesquisada, entre os anos que vão de 1630 a1635.
} 
A presença constante na literatura e sua relação espontânea com o cotidiano das épocas por onde transitou, fez com que don Juan deixasse de ser meramente uma personagem literária para se transformar num mito, cuja a importância e centralidade, o transformaram em registro dicionarizado.

No dicionário Aurélio, há registro tanto do adjetivo dom-juanesco, quanto do substantivo dom-juanismo, ambos derivados de don Juan, embora não faça parte das páginas do dicionário, é ainda constantemente utilizado como adjetivo caracterizador daquele que apresenta um comportamento pautado nas maneiras de agir da personagem.

Os significados colhidos pelos registros do dicionário em relação às expressões confirmam a suspeita de que no curso da história o que efetivamente permaneceu dos modos de ser dessa personagem, foi sua capacidade de envolver por meio da sedução e da sexualidade. A imaginação tratou e ainda trata a figura dom-juanesca, sem distinções. A personagem foi unificada em torno de um único aspecto: a sedução.

Tendo em vista, essa simplificação e homogeneização do papel da personagem no transcurso do tempo, nos parece indispensável, retomarmos as suas peripécias em seu texto fundador, o que nos permite, um olhar mais aprofundado sobre suas origens, ao mesmo tempo em que nos ajuda a melhor referenciar o don Juan nos que se refere aos don Juans da obra de Milan Kundera.

\section{A TRAJETÓRIA DE DON JUAN}

Don Juan, em sua longa trajetória transcendeu ao seu formato original, nesse percurso, apresentou e continua apresentando uma enorme capacidade - diríamos, raríssima, no contexto das obras ficcionais, sejam elas literárias, cinematográficas, musicais ou teatrais - de se adaptar à épocas e situações diferentes. Ao longo deste processo da ficção don Juan se adaptou, se renovou e se reformulou em conformidade com o transcurso do tempo e com as exigências estéticas do seu criador-(re)adaptador.

Embora seja o ponto de partida de uma longa lista, don Juan Tenório de é, hoje, segundo Gonzáles (2004), o menos conhecido do público comum. Isso se deve provavelmente, por seu nome ter sido omitido do título da peça, algo que normalmente não aconteceu em outras aparições da personagem. 
Don Juan Tenório, criado por Tirso de Molina ${ }^{5}$ está inserido numa perspectiva barroca, ele ocupa os espaços sociais de uma época de transição entre o mundo clássico e o mundo moderno é, portanto, inspirado pelos valores supremos que prefiguravam a modernidade.

A racionalidade que coloca o homem no centro das reflexões, e ao mesmo tempo despreza as leis divinas, é o princípio geral que molda o comportamento da personagem. Distante do sentimento de culpa, desapegado das noções de castigo, da punição celestial, don Juan Tenório se apresenta e se configura enquanto um ser desprovido de qualquer sentimento em relação ao outro. Na sua essência é um libertino, é um 'coração de pedra'. Se por um lado, distancia-se das leis divinas, por outro lado, ou talvez por isso mesmo, não há no desenrolar da peça nenhuma demonstração de sentimento por parte dele em relação as suas vítimas. Essa incapacidade de envolvimento com as emoções do outro é que lhe permite distanciamento das conseqüências geradas por suas ações sedutoras.

Aliada da supressão dos valores religiosos, a impossibilidade de sentir o faz agir com tamanha desenvoltura, sem se reprimir. Essa ausência de sentimentos também o destitui da culpa ou do arrependimento. Transformando os males causados as suas vítimas em algo sem importância ou relevância. A ausência de conflitos em don Juan, é de certa forma, uma conseqüência da sua atemporalidade.

Don Juan desconhece o tempo, isto é, seus atos carecem da perspectiva temporal. Assim ele jamais se preocupa com o futuro, (...) Não há projetos, a não ser imediatismos: possuir essa mesma noite a mulher que acaba de conhecer e fugir logo mais. Do mesmo modo, não existe o passado para don Juan: ele jamais reflete sobre seus atos, o que elimina por completo que ele possa carregar a noção de culpa. (...) Sua vida tem, para ele, um sentido de eternidade, pois vê a existência como uma interminável sucessão de instantes independentes. Em última instância, don Juan é isso: a encarnação de um absoluto atemporal que, na falta de uma outra designação melhor, chamamos de "instante". (Gonzales, 2004, p. 27)

\footnotetext{
${ }^{5}$ De origem popular do barroco espanhol, El burlador de Sevilla y convidado de piedra teve a autoria atribuída ao Frei Gabriel Telles que se consagrou escritor dramaturgo sob o pseudônimo de Tirso de Molina. Embora tenham ocorrido várias controvérsias a respeito da verdadeira autoria do texto, o que mais nos interessa nele, entretanto, é o modo como don Juan Tenório se fez e continua a se fazer presente nessa obra.
} 
$\mathrm{Na}$ análise de Gonzáles, don Juan Tenório ultrapassa a condição de mero sedutor, ou mesmo de uma personagem nos moldes tradicionais inspirada no homem. Pode se afirmar que ela é uma espécie de entidade que se manifesta onde e quando há terreno fecundo para isso. Desse modo, as ações do don Juan Tenório de El burlador de Sevilla y convidado de piedra, são estimuladas e resultam da corrosão dos valores éticos e morais da sociedade de seu tempo.

O triunfo sobre os sentimentos das mulheres pode ser explicado também pelo caráter atemporal, visto que elas não poderiam obter sucesso com o amante, na medida em que esperavam dele um projeto de futuro, Tirso de Molina constrói seu texto de modo a revelar diante do público, que essas mesmas mulheres não são apenas vítimas das ações e peripécias de don Juan de Tenório, são fundamentalmente, vítimas das próprias transgressões e ambições as quais expõem a deterioração dos valores ético-morais de uma sociedade que ironicamente se apresenta fundada sob a égide de princípios bem determinados e sólidos.

Desse modo, ao abrir mão de seus princípios quando se depara com don Juan, enxergando nele a possibilidade de participar da nobreza, Tisbea, a artesã, é acima de tudo, vítima de sua ambição e vaidade. Da mesma maneira, as mulheres constituintes da nobreza são punidas por violarem as regras de condutas morais vigentes na corte.

A fragilidade dos valores observada no caráter dessas mulheres é representativa da própria fragilidade do tecido social. Assim, pode se afirmar ser don Juan, para Tirso de Molina, uma espécie de entidade que ao se manifestar desvela e aponta os males presentes na sociedade e no homem de seu tempo. Don Juan transita em todos os espaços, vai desnudando as aparências sociais revestidas com as máscaras que cobrem uma hipocrisia reinante em todas as camadas dessa sociedade, desde a parcela representada pela artesã, até a representada pela nobreza.

Para cumprir essa função no texto, don Juan faz jus da sua condição de entidade com características barrocas,

DOM JUAN EMERGE DO LADO ESCURO da sociedade, irrompe de trás das cortinas, desponta das horas incertas da noite, dos desejos guardados de todos nós. Nele se concentram as projeções não realizadas dos homens e das mulheres, e é por isso que se diz que ele não existe. E, por não existir, é capaz de dizer e fazer tudo aquilo que, ainda que muito secretamente, dele se espera. (Cojorian, 2004, p. 07) 
Gonzálesjá apresenta ao leitor algumas das características da personagem, e já conduzindo-a à condição de entidade, todavia sem referências a uma realidade exterior. Essa condição de Ser inexistente quase fantástico é que lhe permite estar e penetrar nas camadas mais profundas, secretas e intransponíveis dos homens e da sociedade. E é por ser dono absoluto dessa condição de Ser inexistente, que, de modo irônico, don Juan desmascara a estrutura social vigente e aos olhos do público, expõe as corrosões humanas e sociais de sua época.

Convém afirmar que esse modo irônico o qual nos referimos, se dá mais pela percepção geral da obra, que propriamente pelas ações particularizadas de don Juan. É da tessitura, do entrelaçar do texto, que sobressaltam o riso, a ironia, o "deboche". A utilização da figura do gracioso ${ }^{6}$ é um elemento que reforça a compreensão de que a obra de Molina tem um fim orientador, denunciador.

A própria estrutura do texto de Molina leva ao riso imediato, pois, ao contrário da prosa, que exige uma apreensão lenta e gradativa dos sentidos que se insinuam, "no verso, tudo que está oculto se manifesta" e exatamente por cumprir com maestria essa função é que Lukács acredita que "os versos de Dom Juan (...) pertencem à companhia dos grandes humoristas." (Lukács, 2000, p. 58).

No intento de atacar a sociedade, o processo de sedução desencadeado por don Juan, tem uma nítida relação de poder. Interessa-se mais pelo poder da conquista que pelo objeto dela, não são as mulheres ou muito menos o sentimento delas o que interessa como resultados de suas investidas. Ele seduz pelo prazer de se sentir superior ao outro, é a sensação de poder sobre o seduzido e sobre aquele que foi enganado, normalmente o marido, é que move don Juan. Assim as suas ações em busca do poder resultam sempre no riso mediante a ironia. Isto porque,

no exercício do poder, don Juan ataca a sociedade de sua época naquilo que parecia ser o valor mais importante: a honra, fundamentalmente a honra marital. Daí a identificação - que depois resultará redutora - de don Juan com o conquistador de mulheres, identificação que levará a definir como

\footnotetext{
${ }^{6}$ Segundo Gonzáles, a figura do gracioso foi introduzida no teatro barroco em substituição à figura do bobo da corte. O gracioso cumpria um papel pedagógico na peça, seus comentários, suas intervenções levavam o público às percepções desejadas pelo autor. $\mathrm{O}$ gracioso era, dessa forma, uma espécie de portador da mensagem ideológica do texto.
} 
"donjuanismo" a sedução indiferenciada. Dessa maneira, os numerosos "donjuanes" identificados ou identificáveis na realidade social serão apenas uma fragmentária imitação da personagem original. (Gonzales, 2004, p. 29)

Os elementos caracterizadores de don Juan Tenório são em síntese a sedução, que é confirmada assim como instrumento de poder. Os ataques à honra marital, a ridicularizarão do marido enganado ${ }^{7}$, tudo se torna objeto de riso, aquele que é traído não merece ser levado a sério, mesmo que pertencesse a nobreza - ou principalmente por pertencer a ela. Além de não merecer respeito, de ser julgada, a mulher infiel é também objeto de riso porque trai e é simultaneamente traída por don Juan.

Ao atacar a honra marital e revelar a fragilidade dos princípios das senhoras de seu tempo, don Juan desestrutura os pilares sociais abalando nela a coluna mais firme de sustentação: a honra, particularmente, a honra marital, e ao fazê-lo ridiculariza não a um homem em particular, mas tudo aquilo que ele representa dentro da sociedade. Dessa maneira, do artesão ao nobre, do homem à mulher, toda a sociedade sem distinção torna-se objeto de riso, transformar-se em objeto de riso é a punição que cabe a cada um.

Somente quem se livra da punição dos homens é o próprio don Juan Tenório. Não é sua condição social privilegiada quelhe assegura essa isenção, mas acima de tudo sua condição de ser quase fantástico, maravilhoso. Na criação de Tirso de Molina, don Juan é uma personagem que está para além do bem e do mal e completamente isento do julgamento alheio, e o que lhe assegura esse privilégio é sem dúvida sua condição de não pertencimento, é a capacidade de existir sem que haja uma existência objetiva configurada numa realidade externa.

\section{A SEDUÇÃO OS SEDUTORES DE KUNDERA}

Embora não haja nenhum tipo de associação direta à legendária personagem don Juan, há nitidamente, no conjunto da obra de Milan Kundera, a presença ostensiva dessa figura. Independente do gênero, da classe social, bem como de sua posição dentro da obra, central ou

\footnotetext{
${ }^{7}$ Num ensaio intitulado A política de Don Juan, contido no livro A sedução e suas máscaras: ensaios sobre Don Juan (1988), Renato Janine Ribeiro afirma que, por ser a mulher posse ou responsabilidade do marido, do pai ou do irmão, ao atingir a honra dessas mulheres don Juan atinge diretamente a honra de seu protetor.
} 
secundária, as personagens de Kundera são movidas pela pulsão sexual. O comportamento libertino é marca possível de ser identificada em todas as personagens desse autor. Para compreender essas construções de Kundera, há que se tomar como ponto de partida a característica que permeou todos os herdeiros do fenômeno don Juan: sua condição de sedutor. Portanto, para seguir adiante é necessário que se tenha clareza do que aqui se entende por sedutor.

O sentido etimológico da palavra sedução, provém do Latim (se[d] ducere). Além de conjunção adversativa, sed, nos textos antigos, era usado como provérbio com o sentido de "separação" "afastamento" e ou "privação", e ducere, por sua vez, tinha como sentido "levar", "guiar", "atrair". Seduzir era, portanto, o ato de atrair o outro o destituindo da própria autonomia.

O dicionário Aurélio, por sua vez, traz para o verbo seduzir a seguinte definição: "inclinar artificiosamente para o mal, ou para o erro; enganar ardilosamente, desencaminhar; desonrar, valendo-se de promessas; atrair; / encantar; fascinar; revoltar; subornar para fins sediciosos; induzir". Já para a definição do adjetivo sedutor, faz uso do seguinte registro: "adj. Que seduz; que atrai ou encanta; sm; aquele que seduz; o que desonra mulheres".

Há nesses registros, uma conotação bastante pejorativa que, se atrelada à personagem de Tirso de Molina, parece uma aproximação perfeitamente adequada a don Juan Tenório para quem burlar e seduzir eram ações simultâneas e complementares. A própria semântica do verbo seduzir, do modo expresso pelo dicionário é na realidade, uma extensão do sentido da palavra burlar. Contudo, atribuir tais sentidos de modo inadvertido às composições kunderianas, pode-se incorrer num grande equívoco.

Apesar de freqüentemente fazer uso da capacidade de atrair o outro pelos requisitos carnais, muitas vezes em benefício próprio, os don Juans de Milan Kundera não podem ser classificados de modo simplista, tomando como referência única a dimensão presente nos registros dicionarizados ${ }^{8}$. A polifonia contida em cada uma dessas personagens ou no conjunto da obra, não permite qualquer tipo de catalogação ou de registros definitivos e homogeneizados.

Do mesmo modo que é possível observar em Ludvik - A brincadeira- a figura do enganador, do ardiloso em relação á sua vítima Helena, podemos

\footnotetext{
${ }^{8}$ Outro aspecto a ser considerado é o fato de que o dicionário designa como substantivo masculino aquele que seduz ou desonra mulheres, na obra kunderiana, entretanto, aquele que seduz muitas vezes pertence ao sexo feminino.
} 
encontrar em Jaromil -A vida está em outro lugar- a figura daquele que procura encontrar e construir mecanismos que atraiam a atenção, que encante. Já em $\mathbf{O}$ jogo da carona - Risíveis amores - a sedução não pode ser compreendida como nenhuma das alternativas contidas nos registros dicionarizados. O jogo da sedução para a moça, principalmente, não se trata de enganação ou desejo de encantar, de atrair é, acima de tudo, uma representação que lhe permite a fuga de sua insignificância como pessoa e como mulher, ao mesmo tempo em que é uma fuga é também a busca de si mesma.

A sexualidade da forma expressa pela personagem de $\mathbf{O}$ jogo da carona, revela a crise indentitária vivida em todas as suas nuanças nos "paradoxos terminais" da modernidade. O erotismo dessa e de outras personagens representa a busca solitária de um eu confuso e fragmentado. A fuga e a busca do self empreendidos pela personagem estão centradas no desejo de satisfazer mais do que ao outro, a si mesma. As palavras finais da personagem, não são propriamente dirigidas ao seu companheiro, mas a si mesma: "Sou eu, sou eu, sou eu..." (Kundera, 1985, p. 91). Tais palavras revelam a experiência angustiada e solitária da moça que se quer tem um nome próprio, por meio dela ou de sua experiência, o narrador expõe aos olhos do leitor a chamada perda da unidade, que anos mais tarde seria considerada como uma das características da pós-modernidade, .

De modo geral, as atitudes dos conquistadores kunderianos se diversificam no interior dos romances, ou mesmo no decorrer de cada narrativa, o que nos revela as personagens enquanto "egos experimentais ${ }^{10 "}$ das possibilidades da existência humana. Ao analisar a vertigem enquanto uma característica de Tereza, por exemplo, - A insustentável leveza do Ser - Kundera assevera que a vertigem tão presente nessa personagem é uma modalidade da fraqueza humana, é resultado dela, e, segundo ele, esse sentimento é conhecido por todos nós, já que é a fraqueza uma das possibilidades da existência humana. Tereza se constitui assim, em um "ego experimental" que permite ao romancista compreender essa possibilidade.

9 Expressão utilizada pelo autor no livro A arte do romance. A expressão é usada para exprimir os finais dos tempos modernos.

${ }^{10} \mathrm{~A}$ expressão ego experimental é usada frequentemente por Kundera pra designar uma condição de personagem que está além da representação pura e simples da realidade, trata-se de um ser mais autônomo, mais próximo das experiências concretas da vida, com essa personagem, o autor está mais próximo, consegue perceber e avaliar melhor as muitas possibilidades humanas 
Assim é possível afirmar que os don juans que permeiam a obra kunderiana não podem ser analisados sob o aspecto único de suas aventuras eróticas. Tomar como referência somente tal aspecto é reducionismo, já que essas personagens oferecem infinitas possibilidades. A polifonia da narrativa e da estética descontínua das variações, as múltiplas espécies e possibilidades do amor, são algumas dessas possibilidades.

Nesse sentido, a figura de don Juan na obra de Kundera representa uma provocação do autor aos leitores, o narrador desmitifica o amor e o trata como última ilusão do nosso livre arbítrio. $\mathrm{O}$ autor designa as escolhas amorosas, em geral como emanadas de certa nostalgia lírica de um sentimento unitário que já está irremediavelmente perdido. Tudo isso tem fundo por demais humano, que procura a segurança, que é por assim dizer, a imagem de um mundo sem conflitos e sem contradições.

Embora os sedutores kunderianos sejam expressamente tipos experimentais e suas ações sexuais nos conduzam a uma análise sobre as diversas possibilidades da existência e das experiências humanas, não se pode perder de vista que a narrativa trata o próprio ato de sedução como uma pulsão indissociável à condição humana, presente em todos nós, e é por meio dessa pulsão que os vários traços da existência se descortinam aos olhos do leitor.

Embora os fins da sedução se diferenciem, há um fato expresso e emblemático em toda a obra de Kundera: a sedução e o erotismo são o fio condutor da movimentação das personagens no interior dos romances. As personagens agem movidas por esses sentimentos, mesmo que não seja a pulsão sexual o aspecto que sustente a ação do conquistador. O desfecho sexual pode ser um meio, mas nem sempre é um fim para os don Juans desse autor. Não é o ato sexual em si o objetivo maior, até porque, muitas vezes, a conquista é desprovida de uma intenção, de um objetivo.

Das concepções de Martin - Risíveis amores- é possível não só a ilustração dessa afirmativa, mas também a dimensão do que representa 'o jogo' da conquista para um verdadeiro sedutor, para Martin o jogo ultrapassa os níveis de significação do jogador, tem uma existência autônoma, "ele se assenhora do jogador", "é o jogo que mantém o jogador a caminho, que o enreda no jogo e que o mantém nele" (Gadamer, 2004, p. 160). Talvez por isso os sedutores de Kundera no desenrolar desse livro e nos demais, irão manter ou mesmo transformar as suas relações em jogos em que as peças são nada mais que a outra parte e eles próprios.

O que estimula a ação do jogador, não é o outro, mas sim sua capacidade de oferecer obstáculos para que o jogo possa continuar. Dessa forma, a 
duração do amor não extrapola a duração do tempo do jogo porque, desprovidas de sentimentos, sustentadas apenas pelo interesse no jogo, as relações amorosas encontram necessariamente seu fim com o desfecho do jogo, ou como diria Tomas - A insustentável leveza do Ser -, no momento em que conseguisse descobrir e se apossar desse "milionésimo que torna uma mulher diferente da outra" (Kundera, 1995, p. 200). O jogo amoroso, mais do que as peças do jogo, isto é, o outro, configura-se assim numa espécie de descoberta, de luz sobre a vida opaca sem contradições, sem conflitos, em um mundo em que o amor, o erotismo e todas as suas formas encontraram o esgotamento.

Ansioso por permanecer no jogo, como única possibilidade de existência concreta, Martin grande jogador, defende veementemente o prolongamento do jogo no processo da conquista. Para ele, no desenrolar da sedução, além da abordagem, só existe um único e último grau de atividade, mas recorrer a ele como objeto central do jogo é para quem aspira ao status de grande conquistador, no mínimo desprezível. Segundo a personagem,

aqueles que aspiram somente a este último grau são homens miseráveis e inferiores que lembram certos jogadores de futebol do interior que vemos lançar de cabeça baixa na direção do gol do adversário, esquecendo-se de que para marcar um ou mais gols não basta o desejo frenético de chutar, mas é preciso primeiro jogar em campo um jogo consciente e sistemático. (Kundera, 1985, p. 14)

Com as atitudes da personagem perante $\mathrm{o}$ ato da conquista, o narrador nos revela uma face de don Juan: ele passa a ser alguém que tenta, por meio do jogo da sedução, criar armadilhas para sobreviver à pós-modernidade. Se Martin nos revela o desejo de construir um método quase racional para viver o amor, outras personagens como Tereza - A insustentável leveza do Ser -, e Agnes - A imortalidade - optam por um erotismo lírico ${ }^{11}$, pois quando o novo deus permite tudo, cria uma nova forma de ver e sentir o mundo e nele, as relações erótico-amorosas se esgotam perdendo o encantamento é, assim, necessário criar outra forma de erotismo, um erotismo lírico que lhe permita encontrar mais do que ao outro, a si mesmo.

\footnotetext{
${ }^{11}$ Essa concepção de Agnes como don Juan lírico, será mais adiante discutida nesse trabalho.
} 
Embora o ato sexual em si não seja o maior desejo desses don Juans, é, visivelmente, pelo teor sexual que sustenta a rede de sedutores kunderianos, que numa primeira leitura, somos impedidos a associar de modo direto e irrestrito os seus don Juans com aquele de Tirso de Molina.

\section{KUNDERA E MOLINA, SEMELHANÇAS E DIVERGÊNCIAS: UM OLHAR SOBRE O NOSSO TEMPO.}

O paradoxo que mais aproxima os don Juan de Kundera ao de Tirso de Molina talvez seja as condições externas às duas personagens. Enquanto Molina despede-se do mundo clássico prefigurando a modernidade e nela, o homem erguido a status de senhor e dono da natureza, as personagens de Kundera vivem suas aventuras como "os últimos atos dos Tempos Modernos", caracterizado por Kundera como o "período dos paradoxos terminais", segundo ele,

Depois de ter conseguido milagres nas ciências e na técnica, "este senhor e dono" se dá conta subitamente de que não possui nada e não é senhor de nada nem da natureza (ela se retira pouco a pouco, do planeta) nem da História( ela lhe escapou) nem de si mesmo ( ele é guiado pelas forças irracionais de sua alma). Mas se Deus foi embora e o homem não é mais senhor, quem então é senhor? O planeta caminha no vazio sem nenhum senhor. Eis a insustentável leveza do ser. ( Kundera, 1988, p. 41)

As palavras de Kundera reforçam nossa hipótese de que, o que aproxima os dois autores é na verdade a contradição entre eles, se um prefigura o fim de Deus e percebe o homem no centro do universo, o outro desmitifica essa condição humana. Nas criações kunderianas o homem vive a nostalgia da ausência de Deus e de si mesmo como possíveis referências. Nos "paradoxos terminais", assim como o homem, os valores representados pelo humano se degradam e se desintegram, nesse sentido, não há mais nada em que se apegar, não há referências, o vazio se instala na vida e nas relações.

Embora a aproximação entre as personagens de Molina e Kundera se dê exatamente por meio das contradições que envolvem os períodos de transição nos quais se situam, essa associação torna-se natural na medida em que muitos dos sedutores de Milan Kundera trazem como fundamento da personalidade a qualidade que mitificou don Juan Tenório: a de sedutor. Além disso, embora conduzam à reflexões diferenciadas, as atitudes empreendidas no ato da conquista por muitas das personagens kunderianas, apresentam vários aspectos em comum com os modos de agir 
de don Juan Tenório. A frieza, as ações premeditadas, o não envolvimento com aquilo que os circundam ou mesmo com o objeto de suas conquistas e a atemporalidade, são alguns dos traços aparentemente presentes na personalidade dos don Juans de Milan Kundera. Tudo indica que esses são os possíveis elementos condutores dessa aproximação espontânea com a personagem de outrora.

A associação pode se dar porque ela realmente existe, e o escritor deixa entrever isso no segundo ato do conto O simpósio - Risíveis amores. Nele, a passagem intitulada O fim dos dom-juans, valendo-se da voz da personagem Havel, Kundera escreve uma página de reflexões sobre as relações amorosas e conclui que a era de don-Juan está no fim. Como prova disso Havel informa ao leitor, que "O atual descendente de Dom Juan não conquista mais, apenas coleciona”. (Kundera, 1985, p. 113)

Nessa passagem e na seqüência dela no conto, Havel faz a mediação entre a obra kunderiana com a de Molina e ao mesmo tempo, aponta alguns aspectos esclarecedores e contraditórios entre as duas composições. $\mathrm{Na}$ reflexão empreendida sobre don Juan, a voz filosófica de Havel substitui a voz filosófica do narrador, dessa maneira, mesmo não estando presente como narrador autoral nesse momento, ou talvez por isso mesmo, a voz que escreve parece demonstrar o desejo dessa aproximação, mas deixa claro na voz da personagem que, "Dom-Juan" aqui não é uma adaptação ou estereótipo, definitivamente não são a mesma coisa. Das palavras de Havel subtrai-se que não há a intenção do escritor em reproduzir um modelo de conquistador, mesmo porque ressalta as diferenças entre as duas épocas e conclui que

O Grande Colecionador é a morte que veio buscar pela mão a tragédia, o drama, o amor, a morte que veio procurar Dom Juan. No fogo infernal em que foi enviado pelo Comendador, Dom Juan está vivo. Mas o Grande Colecionador, em que as paixões e os sentimentos flutuam no espaço como uma pluma, nesse mundo ele está definitivamente morto. (grifo nosso) (Kundera, 1985, p. 114)

Essa indiferença, contida nas palavras de Havel em relação ao ato da conquista, não é uma regra para outros conquistadores kunderianos. A própria relação da conquista com o jogo observada nesse mesmo livro (Risíveis amores), demonstra que a sedução é para muitos dos don Juans de Milan Kundera, uma espécie de preenchimento de um vazio trazido pela falta de comunicação entre os indivíduos, pela fragmentação, 
desreferencialização, superficialidade e banalidade da vida como um todo, o jogo da conquista é encarado assim, como uma necessidade vital, tem como finalidade principal dar sentido a uma existência flutuante e inútil.

O trecho acima expõe de modo direto aquilo que se evidencia em cada romance, em cada conto, em cada reflexão teórico-ensaísta de Kundera: suas personagens estão inseridas num tempo específico e são elas próprias instrumentos de reflexão do homem e de suas ações e relações nesse tempo. Os sedutores kunderianos são, portanto, portadores das multiplicidades as quais caracterizam a vida e os sujeitos contemporâneos. Daí a importância de se ter clareza de serem as características que perfazem os don Juans que emergem dos textos desse autor bastante sutis e exigirem do analista uma compreensão mais aguçada da obra e do tempo de Milan Kundera.

Mesmo semelhantes, as ações e reações presentes no comportamento dos don Juans contemporaneizados, são resultantes de um modo de viver o cotidiano no nosso tempo. Assim, ao se identificar nas personagens de Kundera, a frieza dada pelo não envolvimento, por uma personalidade aparentemente desprovida de conflitos, esse comportamento remete o leitor imediatamente ao texto original, o que não pode ser tratado como absurdo, já que nele, tais características se fizeram presentes. Porém, é significativa a compreensão de que esse sentimento de ausência tanto do envolvimento quanto dos conflitos ${ }^{12}$ tem seus fundamentos bem mais justificados nos reflexos do mundo contemporâneo, que por qualquer outro motivo.

$\mathrm{Na}$ medida em que os conflitos e as angústias humanas são sentimentos que surgem mediante a uma situação em que um paradigma é questionado ou quando há ruptura de um valor, princípio, modelo ou verdade; na condição presente, tais sentimentos parecem improváveis já que, o homem se diluiu e se perdeu numa massa humana de indivíduos que cada vez mais têm as ações pautadas no pluralismo. O que se observa, portanto, é que os conflitos que ainda perpassam os sujeitos na contemporaneidade são resquícios da modernidade, isto é, são muito mais uma manifestação de valores assegurados pela racionalidade e coerência modernas, visto que

${ }^{12}$ É importante que se lembre aqui que nem todas as personagens dom- juanescas de Kundera apresentam essa ausência de sentimentos ou conflitos, Ludvik de A brincadeira pode figurar como um bom exemplo disso, sua conquista é elaborada de forma ardilosa guiada por um dos mais profundos sentimentos da existência: a vingança. Mesmo que o final do livro desfigure esse sentimento por meio do riso, é ele que move a personagem do início ao fim nesse romance. 
nos "paradoxos terminais", o homem caminha no sentido de eliminar os conflitos e as angústias em favor da negociação, da relativização.

A relativização em detrimento dos conflitos é um elemento ilustrado de modo significativo em A brincadeira. Nesse romance, Ludvik é conduzido do início ao fim pelo sentimento de rancor, como ele próprio define na primeira página do livro: "aquilo que chamava indiferença era na verdade rancor". Mas é no final do livro que descobre a inutilidade de toda a sua ação, percebe que na realidade fizera um grande favor ao seu objeto de vingança (Pavel), sem falar no fim hilário do 'instrumento' da vingança (Helena), que após perceber o desprezo de Ludvik e de seu suposto marido traído, tenta o suicídio, mas ao fazê-lo toma enganada, laxativos.

Com esse final, Kundera definitivamente desconstrói, por meio do riso, a permanência dos sentimentos ou valores tão arraigados entre os homens, demonstrando assim que os nossos conflitos são existenciais, nesse sentido quaisquer sentimentos que fujam a essa busca interior vivem seus últimos suspiros. O estilo de vingança empreendido por Ludvik talvez pudesse ser bem mais alimentado se a personagem estivesse inserida numa estética e sobretudo numa moral dos don Juans românticos.

Se os conflitos e os embates calcados na força vivem seus momentos finais, há que se criar condições de tornar-se atrativo, de convencer o outro não por meio da força, mas pela sedução. Assim, a capacidade de seduzir parece-nos emergir da obra de Kundera também como uma necessidade e uma importante ferramenta na vida do homem contemporâneo em todos os aspectos de sua existência. Inserido nessa perspectiva, Jaromil é uma personagem que bem representa essa percepção do presente. Além de sua capacidade de atrair as mulheres, Jaromil se faz poeta na medida em que vai percebendo, desde a infância, como seu discurso poderia ser usado em proveito próprio, ao perceber a atração que as palavras faladas ou escritas exercem sobre as pessoas, nosso poeta, se dá conta da necessidade de elaborar e construir seus discursos, com o intuito único de ser observado, ouvido e admirado. O discurso torna-se assim, para Jaromil, a mais poderosa ferramenta de sedução que será usada com singularidade por toda a sua existência.

Kundera parece usar silenciosamente o don Juan de El burlador de Sevilla, como um texto de partida para suscitar a complexidade de sua escrita, mas esta técnica de narrar os procedimentos da personagem está longe de ser um retorno ao passado ou uma aproximação objetiva com a personagem idealizada pelo dramaturgo espanhol. As relações com a 
personagem barroca, bem como com suas heranças, inserem o texto de Milan Kundera numa perspectiva de dialogicidade discursiva, o que traz à tona as múltiplas identidades de don Juan apresentadas ao longo da história literária, e ao promover o diálogo entre as duas épocas o escritor realoca as diversas possibilidades da personagem no tempo presente: assim como a contemporaneidade é múltipla, os don Juans são múltiplos, neles a heterogeneidade resultante desses múltiplos formatos que adquirem a personagem em cada uma de suas manifestações é um fato.

Embora muitos dos romances de Kundera sejam tecidos pelos fios da memória, a fixação da vida num eterno presente é algo possível de ser identificado nas suas personagens, elas são seres preocupados em viver o momento, não há um projeto de futuro, nem vínculo aprofundado com o passado. Em A Ignorância, por exemplo, as personagens retornam a sua terra natal após o exílio e por meio dos reencontros entre amigos, entre familiares e entre antigos amores, procuram manter contato com as Histórias de suas vidas. Essas personagens, assim como várias outras personagens kunderianas, não são exiladas somente de sua pátria, são exiladas de si mesmas, desse modo, vagam em busca de si mesmas. Assim, o exercício de retorno à cidade natal, se configura no exercício de reconstituição do eu. É também por isso que Tamina em $\mathrm{O}$ livro do riso e do esquecimento se desespera com a perda gradativa da memória, pois o esquecimento representa o desfacelamento de si mesma, de seu eu. O romance kunderiano parece propor a seguinte pergunta: sendo a identidade ligada à memória, esvaindo-se a memória, onde fica o eu? Nesse sentido, o retorno das personagens pode ser interpretado como uma forma de encontrar esse eu perdido e fragmentado dentro de uma crise identitária imposta pelos rumos do exílio da subjetividade humana.

O 'presenteísmo' das personagens kunderians, pode perfeitamente levar o leitor mais uma vez a associações com a atemporalidade contida naquela personagem de Tirso de Molina. Porém essa atemporalidade não resulta de uma não existência, porque os seres ficcionais de Kundera não são entidades preocupadas em apontar ou revelar para o leitor as mazelas sociais do modo como o faz don Juan Tenório no século XVII. Embora ainda dentro de uma perspectiva moderna, as personagens kunderianas já se mostram mais distanciadas de uma preocupação ética ou moral dominante, elas já se colocam em muitos casos de acordo com os preceitos da pós-modernidade, nesses momentos, apenas representam o cotidiano, deixando a cargo do leitor a tarefa de identificar, por meio da própria sensibilidade, os temas 
ali representados, dialogados e, muitas vezes, pensados e refletidos seja nas muitas vozes que constituem o romance, seja na voz filosófica do narrador autoral.

Embora se perceba certo conflito próprio de quem vive nos limites das fronteiras entre o Moderno e o Pós-moderno, ao contrário do texto espanhol em que as distorções são desnudadas com certo rigor diante do público, no romance kunderiano os sentidos se insinuam pouco a pouco para o leitor, não são colocados como verdades absolutas, mas como possibilidades.

O presenteísmo do qual estamos falando é mais uma das características desse universo.

O tempo se contrai no espaço. Em resumo, o que vai predominar é um presente em que vivo com outros em um dado lugar. (...) trata-se de um "carpe diem", de antiga memória, traduzindo um hedonismo difuso. O prazer não é mais adiado para hipotéticos "amanhãs cantantes", ele não é mais transferido para um paraíso a chegar, mas vivido bem ou mal no presente (Mafesoli, 2001, p. 25)

Embora a denominação don Juan resulte de uma associação com as semelhanças em relação ao comportamento sedutor de don Juan de Tenório de El burlador de Sevilla y convidado de piedra, e talvez com os que o sucederam, os homens e mulheres donos dessas semelhanças no romance kunderiano, extrapolam a condição de meros conquistadores, quer sejam coração de pedra, quer sejam mais humanizados por meio dos sentimentos. Somos tentados a dizer que, eles são acima de tudo, representações de um modo particular de ver, pensar e sentir o mundo e o homem no vislumbrar da pós-modernidade.

Da mesma forma que a humanidade começa a perder definitivamente a condição de totalidade, se fragmentando, se pluralizando, Kundera não apresenta um modelo definido da personagem don Juan, ela varia de acordo com o espaço, com as circunstâncias ou como diria Mafesoli 'com as tribos a que pertence'. Assim como o homem e o mundo contemporâneo, os don Juans kunderianos são personagens múltiplas, fragmentárias, mesmo quando se trata da mesma pessoa.

Destituídos de regras, normas, e modelos nos quais possam justificar suas maneiras de agir e de ser, o homem na contemporaneidade dispõe exclusivamente da sua capacidade de convencer pela argumentação, pela sedução. A ausência de um paradigma modelo nos nossos tempos faz com que tudo seja menos determinado e imposto e, conseqüentemente, mais relativizado. "A verdade absoluta, que é preciso atingir, fragmenta-se em 
verdades parciais que convém viver" (Mafesoli, 2001, p. 23). Sobrevive no mundo dos negócios, da política, na vida pública e privada em geral, o indivíduo que saiba ponderar, que saiba negociar e convencer, que seja portador da capacidade de seduzir por meio do discurso, da ação, que saiba enfim, criar uma imagem focada fundamentalmente nesses aspectos.

À medida que se envereda pela obra de Kundera, percebe-se que as características a que associamos ao don Jaun de El burlador de Sevilla, são na verdade, características próprias do homem do tempo do autor. A frieza que normalmente caracteriza as suas personagens, por exemplo, não parecem ser resultantes de um coração de pedra, como no texto original, mas sim, resultam de uma indiferença generalizada em relação ao outro e a aquilo que acontece a sua volta, atitudes próprias da existência humana no presente.

A importância da fixação dessa personagem num tempo específico: o fim da modernidade e o início da pós-modernidade pode ser relevante para compreender sua presença tão ostensiva e ao mesmo tempo tão diluída na obra de Kundera. Ostensiva porque é marca de todos os romances, e diluída porque, como já foi anteriormente dito, não há um don Juan com características e ações bem definidas e específicas dentro do conjunto da obra ou mesmo em um romance separadamente, o que há verdadeiramente são presenças de tipos diferenciados, multifacetados, que se modificam de um texto para o outro, o que torna impossível um olhar totalizador sobre a obra e mais ainda sobre a personagem, até porque é possível encontrar mais de um arquétipo de don Juan coexistindo paralela e simultaneamente, num mesmo romance. Uma melhor compreensão dessas personagens talvez possa se dar por meio de uma leitura cronológica da obra.

\section{AS MUITAS FACES DE DON JUAN NA OBRA DE MILAN KUNDERA}

Em A cortina, ao relatar uma anedota que envolve a compreensão de seu pai em relação à obra de Beethoven, Milan Kundera abre espaço para expor o valor dado à "consciência da continuidade histórica". Nessas considerações a posição do autor ante as obras de seus autores prediletos pode ser bastante sugestiva para o analista de sua própria obra, numa espécie de desejo particular, o autor inicia sua discussão teórica ${ }^{13}$ confidenciando que

\footnotetext{
${ }^{13}$ Se é que se pode dizer que A cortina trata-se de um texto teórico, essa obra de Kundera, revela um hibridismo de forma que oscila entre ficção e teoria.
} 
$\mathrm{Na}$ época da minha primeira juventude, eu conhecia, de modo inteiramente natural, sem forçar, a cronologia exata das obras de meus autores prediletos. Impossível pensar que Apollinaire tivesse escrito Alcoóis depois de Caligramas, pois, se esse fosse o caso, seria outro poeta, sua obra teria outro sentido. Gosto de cada quadro de Picasso por si mesmo, mas também de toda a obra de Picasso vista como um longo caminho, cuja sucessão de etapas conheço de cor. (Kundera, 2006, p. 12)

Mesmo que na seqüência dessa discussão enverede pelo caminho da consciência histórica em relação ao prazer estético ${ }^{14}$, no trecho acima, podese perceber o grau de importância atribuído não só a análise cronológica, mas também a necessidade do conhecimento da obra de quaisquer artistas que se tenha a pretensão de conhecer.

Seguindo essa orientação do autor, nesse momento da discussão pretende-se um olhar analítico sobre a produção romanesca de Milan Kundera, tomando como referência as obras que, segundo nossa percepção, encontram-se em momentos estratégicos de seu processo criador. A brincadeira, por ser o primeiro romance, A vida está em outro lugar, por ser a primeira a introduzir a figura do narrador-autor, Risíveis amores, por tratar-se de um apanhado de casos dom-juanescos, $\mathbf{O}$ Livro do riso e do esquecimento $e$ A insustentável leveza do Ser, por serem o momento de aprofundamento e talvez de amadurecimento de temas tratados pelo autor, A imortalidade por inaugurar uma nova forma de escritura, bem como por ser um texto escrito em outro momento da história do autor, e por fim, A lentidão, romance que se apresenta como um laboratório onde o autor confirma de modo audacioso - por meio de dois don juans - as experiências da existência humana no início e no fim da modernidade.

Nessa trajetória consideraremos também como ponto de reflexão os manuais teórico-ensaísticos, momentos em que o autor expressa, por assim dizer, uma preocupação e simpatia pelo romance e pela condição de romancista, da mesma forma, revela uma necessidade de intervir na compreensão de sua produção ficcional. Necessidade que se evidencia já nas suas primeiras narrativas quando o narrador se interpõe por diversas

\footnotetext{
${ }^{14}$ A discussão acerca da consciência histórica versus prazer estético, envergada nesse texto, refere-se à relação do prazer com a racionalidade, ou seja, podemos sentir grande prazer diante das composições de Beethoven, mas uma composição do mesmo estilo assinada por um compositor de nossos dias com certeza não provocaria em nós esse prazer, teria bem mais facilidade em provocar mesmo o riso.
} 
vezes nas falas e pensamentos das personagens fazendo comentários e tentando de certa forma, conduzir o entendimento do leitor. É certo que o narrador autoral tem primordialmente a função de credibilizar no texto as reflexões nele propostas, já que muitas de suas representações no percurso das obras extrapolam o conceito de verossimilhança ${ }^{15}$, contudo, acreditamos também nessa outra possibilidade: a de garantir certo controle das reflexões propostas no interior da narrativa.

Dessa forma, acreditamos que a compreensão dos don Juans de Kundera sugere um entendimento acerca do processo de criação, bem como da relação desse autor-narrador com sua obra, uma vez que a movimentação dessa personagem parece ser - segundo o que se pode observar no pensamento teórico do autor- estrategicamente planejado sob uma concepção reflexiva do criador.

Don Juan se constituiu na obra de Kundera desde a primeira página do primeiro livro, no triângulo amoroso de cada obra, a figura dom-juannesca é sem dúvida o centro em torno do qual gravitam as outras partes. Don Juan é desse modo, uma espécie que emerge das linhas e entrelinhas como um verdadeiro cenário a ser explorado pelo autor é sempre o ponto de partida escolhido por ele. Podendo assim ser definido: uma linha que nos permite o entrelaçamento dos fios que tecem a obra de Kundera, e nela, o pensamento e a compreensão da narrativa romanesca por ele empreendida.

Segundo Lukács (2000), a compreensão do romance se dá por meio do acúmulo dos sentidos que vai aos poucos, passo a passo, se construindo por meio de relações estabelecidas no decorrer da narrativa. Na obra de Kundera, os don Juans são os principais elementos constitutivos desses sentidos, mas o que os torna singular é que esses sentidos ultrapassam os limites de um romance, eles se prolongam no conjunto da obra. O que equivale a dizer que muitas vezes só se conhece mais profundamente um texto desse autor mediante a leitura de um outro, é o que acontece, por exemplo, com A insustentável leveza do Ser $e$ A imortalidade que embora escritos em tempos e espaços diferentes, os dois são textos contínuos, um é notadamente o prolongamento das reflexões do outro.

${ }^{15} \mathrm{O}$ que nos leva a essa proposição é o próprio modelo narrativo adotado por Kundera. Ele apresenta um texto que vai além da proposição aristotélica de verossímil, quando traz para dentro do romance uma realidade ficcional composta por uma variação textual constante que não apenas representa, mas que descreve a realidade vivida e muitas vezes se confunde deliberadamente com ela. 
As múltiplas faces de don Juan na obra kunderiana são reveladas aos poucos, numa trajetória que obedece ao próprio tempo do autor. Os conquistadores por ele criados não se submetem a uma análise unilateral ou que tome como referência um único romance, pois a impressão que se tem é que o autor vai aos poucos construindo essa personagem com toda a gama de complexidade que envolve os seus universos exteriores e interiores, assim, como bem disse o autor, os don Juans aqui devem ser percebidos dentro do caminho percorrido pela obra os quais são resultantes da caminhada de Milan Kundera, seja como romancista, seja como sujeito/ indivíduo inserido num contexto de transformações históricas.

Lendo os romances Kunderianos dentro de uma perspectiva cronológica, podemos nos dar conta do modo pelo qual o escritor vai captando gradativa e sensivelmente as complexidades que envolvem as causas humanas e o mundo de seu tempo e como essas complexidades são transcritas na obra e nela, pensada gradualmente. Assim, embora independentes nas narrativas, em um leitura cronológica, percebemos que os don Juans de Kundera são complementares, eles revelam essa compreensão gradativa do autor em relação ao seu mundo e seu tempo e qualquer estudo que não levasse em consideração tal questão, necessariamente revelaria sua incompletude.

Dessa maneira, aqui se pretende um olhar sobre os don Juans que transitam na obra literário-reflexiva de Milan Kundera a partir de uma linha do tempo. Tal atitude procura observar como esta personagem foi se estabelecendo e se transfigurando no percurso histórico dos romances desse autor.

O primeiro romance de Milan Kundera A brincadeira ${ }^{16}$ foi publicado em 1967, nele, o autor já prenunciava a figura dom-juanesca, representada por Ludvik. O próprio Kundera deixa claro, quando se refere ao livro, que ele nasceu de suas análises e observações do cotidiano, particularmente sobre as relações afetivas que envolvem os seres humanos nos nossos tempos. Segundo ele, sua história nasceu com a imagem da jovem operária que fora presa roubando flores e para quem o amor e a carne eram coisas separadas, para quem a sexualidade era o oposto do amor.

\footnotetext{
${ }^{16}$ Esse romance foi retirado de circulação no período da invasão soviética a Tchecoslováquia. O teor político dado a obra nesse período foi segundo o próprio autor, esquecido pelos exploradores, segundo ele, A brincadeira pôde "voltar enfim a ser o que sempre quis ser: apenas um romance, e nada mis do que um romance"
} 
Em A brincadeira, Ludvik volta a Praga sua cidade natal, para efetuar sua vingança, contra Pavel, a quem considera culpado pela expulsão do partido e também de seu país e por quem, por esses motivos, nutre grande rancor. As frases, "eu corro atrás de mulheres" ou "É (...) ele vai me permitir efetuar uma bela destruição." (Kundera, 1986:13,15), as quais marcam o início das falas da personagem, são permeadas pela característica mais evidente de don Juan, aquela que o mitificaria: a disposição sexual aliada ao distanciamento para com os sentimentos do outro.

Nesse romance, Kundera já traz alguns dos traços marcantes de seu estilo. O primeiro deles revela sua opção por uma estrutura fragmentada em que muitas vozes se manifestam a partir do próprio ponto de vista, além de representar as dificuldades de comunicação entre os indivíduos que se acentua. Embora no plano das idéias as personagens tenham plena consciência do outro e suas vozes sejam confrontadas o tempo todo por meio do diálogo, com a estrutura formal escolhida pelo autor, as personagens não se encontram efetivamente. As ações e pensamentos são apresentados isoladamente, elas, entre si, não compartilham nada, mesmo quando fisicamente se encontram, a comunicação se mostra difícil. Assim como na vida que se afigura com a pós-modernidade, as criações kunderianas nesse livro permanecem isoladas e solitárias no decorrer da narrativa. Desse modo, a estrutura expõe também a instabilidade e a fragilidade das relações humanas, principalmente as amorosas, as quais se sustentam fundamentalmente na a relação carnal. A interação comunicativa concreta no romance é quase que inexistente, as pessoas não conseguem se relacionar, a aproximação se dá basicamente por meio das relações estabelecidas pela ação do autor que nesse caso, demonstra manter a percepção do todo dentro e fora do romance, tornando-se um organizador eficiente das consciências no interior do romance.

A escrita de Milan Kundera assim como seu tempo, rejeita qualquer tipo de sentimentos exacerbados de apegos que pesem sobre os seres. Não há pretensão de julgar, vingar-se, desnudar seja o que for, o que interessa a esse autor desde o início, é a representação de um homem e de um mundo inseridos numa época determinada: aquela pré-figura daquilo que se convencionou chamar de pós- modernidade, lugar onde os grandes sentimentos, valores ou modelos não encontram espaço para se reproduzir e se fortalecer. Assim, como o mundo e o homem de seu tempo, a representação kunderiana, por um lado vive os conflitos de quem não abandonou por completo os princípios modernos, mas por outro lado tem 
a consciência de não se prender a eles, está mais próxima da fluidez pósmoderna, se move constantemente no fluxo dos acontecimentos presentes, tudo é efêmero e passageiro tudo é representação.

Se por um lado, essa fluidez destituída de uma carga de densidade psicológica se traduza por meio de uma linguagem simples e direta, quase objetiva, por outro lado, em A brincadeira, Kundera desconstrói da forma mais desmoralizadora - por meio do riso e da ridicularização - o apego ao sentimentalismo moderno, e é nessa destruição que o autor se reconstrói para uma nova proposta narrativa apontando assim, já nesse primeiro volume, a direção e o teor de sua obra: a leveza, traço indissociável à narrativa kunderiana.

Ao mesmo tempo em que conserva os traços de A brincadeira, em A vida está em outro lugar, a narrativa adquire novas perspectivas de complexidade, a começar pelos três mundos habitados no romance pela personagem dom-juanesca. Jaromil é simultaneamente uma espécie de ser concreto e real do texto, é também Xavier que habita o mundo dos sonhos e Rimbaud que se trata de uma reconstrução do passado. Nessa construção Kundera aborda três temas que se farão presentes em suas reflexões posteriores: o presente que se caracteriza pelo ser no mundo, o onírico e a memória.

Esse romance de Kundera é significativo enquanto marco inicial de umas das características mais interessantes, e talvez mais instigantes da obra desse autor: a presença do autor no interior do romance. Ainda que aqui o autor se presentifique de uma forma mesmo que tímida, apenas com o eco de seu pensamento é nesse momento da obra de Kundera que ele demonstra certa inquietação quanto sua postura narrativa, não mais se conforma em apenas narrar seu texto, começa a se interpor com considerações, observações que lhe permitem explicar suas tomadas de decisões, bem como suas escolhas. Ao renunciar sua posição de 'neutralidade', assume um papel de autoridade narrativa efetiva, garantindo, portanto, a credibilidade reflexiva de seu romance.

Risíveis amores segunda obra kunderiana é uma espécie de tributo ao dom-juanismo, nesse livro, Kundera faz um amplo estudo de casos, reafirmando junto ao leitor a simpatia e a ligação para com essa personagem. Se em A brincadeira nos apresenta seu primeiro formato de don Juan, com Risíveis amores, Kundera consolida a figura dom-juanesca enquanto centro das reflexões de sua obra. Nos sete contos que compõem essa narrativa, a figura de don Juan salta aos nossos olhos com todos os formatos, cores e 
gestos possíveis. Percorrendo o livro, nos deparamos com o don Juan quase ingênuo e adorável representado por Martin, passamos pelas angústias solitária do isolamento vivenciado pelo casal (dupla de don Juans), de $\mathrm{O}$ jogo da carona e mais adiante nos deparamos com o decadentismo do don Juan representado pela segunda versão de Havel. Nesse don Juan, vítima do envelhecimento, pode-se constatar que em nossos dias a punição não vem pelas leis divinas ou dos homens, mas pelas leis do tempo. Porém sendo um eterno conquistador, precisa encontrar outras formas de seduzir, a imagem da mulher, famosa atriz de cinema é a única ferramenta de que agora dispõe.

Ao mesmo tempo em que em Risíveis amores ressalta sobremaneira a importância da figura de don Juan, na compreensão do conjunto de sua obra, com esse mosaico dom-juanesco o autor parece expor as diversas possibilidades dessa personagem no interior de suas criaç2ões. Porém, continuando a incursão pela narrativa kunderiana pode-se perceber que as diversas possibilidades de que falamos, de modo algum se esgotam nessa coletânea. Don Juan continuará sua trajetória na obra de Kundera, como espelho individual por onde se reflete a imagem das experiências humanas dentro da História factual.

Sobre essa percepção da relação História exterior versus história interior o autor retoma a fórmula heideggeriana do "estar-no-mundo" ${ }^{17}$ e assegura que

O homem não se relaciona com o mundo como um sujeito com o objeto, como o olho com o quadro; nem mesmo como um ator no cenário de um palco. $\mathrm{O}$ homem e o mundo estão ligados como o caramujo e sua concha: o mundo faz parte do homem, ele é sua dimensão e, à medida que o mundo muda, a existência (in-der-welt-sein) muda também. (Kundera, 1988:36)

A Insustentável leveza do Ser é o romance em que Kundera irá aprofundar todas as possibilidades dessa relação do ser com o mundo, iniciadas nos romances anteriores. A leveza, o onírico, o conflito da relação corpo e espírito vivido por Tereza, da qual mais uma vez emerge as incertezas do eu e da identidade, sem falar no Kirsch, são bons exemplos de temas

${ }^{17}$ A utilização da teoria de Heidegger sobre o "estar- no- mundo" é feita pelo autor em A arte do romance quando discorre sobre as relações homem $\backslash$ mundo. Por isso a presença dessa teoria aqui ocorre na voz e nas relações do autor. 
suscitados nos romances anteriores e aprofundados com maior densidade em A insustentável leveza do ser.

Segundo o próprio autor, "todos os romancistas só escrevem, talvez, uma espécie de tema (o primeiro romance) com variações.” (Kundera, 1988:121). Nesse quinto romance, pode se dizer que o autor experimenta com profundidade seu próprio pensamento, nele percebe-se o amadurecimento em torno de vários temas empreendidos pelo narrador desde a primeira narrativa. Para desenvolver as reflexões em torno desses temas cria-se um dos arquétipos mais instigantes de don Juan: Tomas

O relacionamento amoroso com Tereza, experimentado num triângulo no qual se insere Sabina, revela duas faces contraditória desse don Juan. Ao mesmo em que se mostra um conquistador envolvido com os sentimentos da mulher amada, Tomas sente necessidade de buscar novas e constantes relações amorosas. Embora sinta o peso do amor confuso de Tereza e tenha necessidades de novas aventuras, a relação afetiva que nasce da fragilidade e da insegurança de Tereza, é para ele uma necessidade vital, assim como a busca incessante de outras amantes também o é. Pensando assim, Tomas, - reforçando e aprofundando o sentimento que impulsionou a escrita de A brincadeira, como nos revela seu criador - desvincula amor e sexo, ao deduzir que "O amor, não se manifesta pelo desejo de fazer amor, esse desejo se aplica a uma série inumerável de mulheres, mas pelo desejo do sono compartilhado (este desejo diz respeito a uma só mulher)" (Kundera, 1995, p. 21). Mais adiante persegue a mesma idéia e conclui que "associar o amor à sexualidade é uma das idéias mais bizarras do Criador" (Kundera, 1995, p. 238).

O próprio romancista tenta lançar um pouco de luz sobre as ações contraditórias da personagem, para isso discorre sobre duas concepções de don Juan, o épico e o lírico. Concepções essas, fundamentadas em "a estética de Hegel" segundo a qual "o lírico é a expressão da subjetividade que se confessa; o épico vem da paixão de se apossar do mundo" (Kundera, 1988, p. 121).

Ampliando o conceito de lírico e épico desenvolvido por Hegel, Lukács (2000) defende que essas duas concepções são possíveis a partir da compreensão do mundo helênico e do mundo moderno. O herói épico, ao contrário do lírico, tem uma percepção da totalidade, ainda não se fragmentou, portanto desconhece as angústias e os conflitos existenciais nas suas caminhadas. Segundo Lukács, "ao sair em busca de aventuras e vencê-las, a alma desconhece o real tormento da procura e o real perigo da 
descoberta, jamais põe a si mesma em jogo; ela ainda não sabe que pode perder-se e nunca imagina que terá de buscar-se."(Lukács, 2000, p. 26). O mistério da imanência de sentidos do mundo helênico reside no fato dos gregos conhecerem "somente respostas, mas nenhuma pergunta somente soluções (mesmo que enigmáticas), mas nenhum enigma, somente formas, mas nenhum caos." (Lukács, 2000, p. 27). O conquistador épico poderia ser dessa forma, entendido como um sedutor objetivo, sabe exatamente onde vai e por que vai, não se perde, é quase previsível. Se por um lado não se decepciona por outro, segundo o narrador de $\mathbf{A}$ insustentável leveza do Ser, não encanta as mulheres isto porque, "como o homem não projeta nelas um ideal subjetivo, tudo lhe interessa e nada pode decepcioná-lo. Essa incapacidade para a decepção tem qualquer coisa de escandaloso." (Kundera, 1995, p. 202).

Já a concepção lukacsiana do lírico refere-se à perda da unidade no mundo moderno. Essa perda da totalidade força o indivíduo a ir buscála e a trajetória nessa busca torna-se uma forma de autoconhecimento. $\mathrm{O}$ homem sai à procura de si mesmo, do eu agora fragmentado. Para Lukács, "o processo pelo qual foi concebida a forma interna do romance é a peregrinação do indivíduo problemático rumo a si mesmo." (Lukács, 2000, p. 82), essa peregrinação é solitária, realizada dentro de um discurso monológico ${ }^{18}$. Por isso o narrador de $\mathbf{A}$ insustentável leveza do Ser afirma que os conquistadores líricos "Procuram a si próprios nas mulheres, procuram o seu ideal e são sempre frustrados, porque, como sabemos, é impossível encontrar o que é ideal." (Kundera, 1995, p. 202)

Em A insustável leveza do Ser, é possível afirmar que Tomas encarna as duas concepções de conquistador: é lírico quando vive seu amor com Tereza e, é épico diante de suas várias amantes. Sabina, é a primeira a se dar conta da dubiedade de Tomas, segundo ela Tomas é "O encontro de dois mundos. Uma dupla exposição. Por detrás da silhueta de Tomas, o libertino, transparece o rosto inacreditável do romântico apaixonado ${ }^{19}$. Ou então é

\footnotetext{
${ }^{18} \mathrm{Faz}$ importante ressaltar que a obra kunderiana é por excelência, dialógica, na medida em que se pode observar um diálogo continuo entre os vários romances, bem como entre o narrador e as personagens. O termo monológico se aplica aqui à interioridade das personagens.

${ }^{19}$ Segundo o próprio Kundera em A arte do romance, devido a pouca familiaridade dos franceses com relação à concepção hegeliana do épico e do lírico, ele foi forçado a permitir que na tradução o conquistador lírico se tornasse o amante romântico, e o conquistador épico o amante libertino. (1988: 121)
} 
o contrário: através da silhueta do Tristão que só pensa em sua Tereza, percebe-se o belo universo traído do libertino." (Kundera, 1995, p. 28).

A narrativa é conduzida do início ao fim tendo como um dos centros de reflexão esse comportamento dúbio de Tomas, o que por momentos suscita o riso e por outros suscita uma reflexão sobre essa relação com o sexo oposto. As duas passagens a seguir ilustram tal afirmativa.

Sua situação não tinha saída: aos olhos de suas amantes estava marcado pelo estigma infamante de seu amor por Tereza, aos olhos de Tereza pelos estigmas infamante de suas aventuras com as amantes. (Kundera, 1995, p. 29)

Os caçadores de mulheres podem facilmente ser divididos em duas categorias. Uns procuram em todas elas sua própria idéia de mulher, como lhes aparece em sonho, subjetiva e sempre a mesma. Outros são levados pelo desejo de tomar posse da infinita diversidade do mundo feminino objetivo. (...) Na sua caça a novos conhecimentos, os sedutores épicos (é nessa categoria que temos que colocar Tomas) se distanciam cada vez mais da beleza feminina convencional (da qual enjoam bem depressa) e acabam tornando-se colecionadores de curiosidades. Eles sabem disso, sentem um pouco de vergonha e, para não constranger os amigos, evitam aparecer em público com as amantes. (Kundera, 1995, p. 202)

Essa modalidade de conquistador é uma espécie que foi aos poucos se moldando na obra de Kundera. A dubiedade da relação de Tomas e Tereza, que o torna um conquistador simultaneamente épico e lírico, começa a se formar já em Risíveis amores. Martin é uma personagem que demonstra certo delineamento dessa relação, que posteriormente se configura com Karel e Markéta em $\mathbf{O}$ livro do riso e do esquecimento, publicação que antecede a $\mathbf{A}$ insustentável leveza do Ser. Porém é Tomas que recebe essa conceituação, com ele, portanto, é que a atitude épica e lírica dos conquistadores kunderianos, torna-se autônoma no conjunto da obra.

Esse formato de relação vivido por Karel e Marketa e por Tomas e Tereza irá se configurar ainda na narrativa bem antes de $\mathbf{A}$ insustentável leveza do Ser: A valsa dos adeuses. Com o relacionamento de Klima e de Kamila o autor reafirma essa concepção de lírico e épico na sua historiografia literária, mas a partir do próximo romance o triângulo amoroso vivido por essas personagens, nesses três romances, recebe outros ingredientes que tornarão ainda mais complexas e ambíguas as posições de cada um no círculo de suas vivências amorosas. A imortalidade é sem dúvida um aprofundamento do don Juan lírico, tão densamente representado na figura de Tomas. 
Além de ser o primeiro livro ambientado num cenário francês, $\mathbf{A}$ imortalidade chama a atenção, sobretudo neste trabalho, pelo formato do triângulo amoroso composto por Paulo, Agnes e Laura. Agnes nasceu de um gesto que segundo o narrador-autor, trata-se do mais individual dos traços, mais individual até que o próprio indivíduo. A figura de Agnes combina em tudo com o processo de sua criação. Agnes percorre o romance do início ao fim em busca de seu eu. Laura, a irmã é no romance, uma espécie de espelho refratário do eu de Agnes. Segundo o narrador,

Há dois métodos para cultivar a unicidade do eu: o método aditivo e o método subtrativo. Agnes subtrai de seu eu tudo que é exterior e emprestado, para desta forma aproximar-se de sua essência pura (correndo o risco de chegar a zero com essas subtrações sucessivas). O método de Laura é exatamente inverso: para tornar seu eu mais visível, mais fácil de ser apreendido, para dar-lhe mais consistência, ela acrescenta-lhe sem cessar novos atributos, aos quais tenta se identificar (correndo o risco de perder a essência do eu sob esses atributos adicionados). (Kundera, 1990, p. 102)

Acreditamos ser possível nesse sentido uma aproximação talvez não da relação, mas principalmente das contradições ambíguas que ao mesmo tempo em que separam esses eu, também são importantes como contraponto para melhor compreendê-los. São exatamente as contradições entre Laura e Agnes que dão a dimensão dos conflitos existenciais vividos por Agnes na solidão em busca de si mesma. Essa mesma solidão, angústia e inseguranças do eu que vaga numa crise sem saída vividas por Agnes, podem ser perfeitamente observadas em Tereza, Markéta e Kamila,(esposas) contudo, vale ressaltar que com Agnes esses aspectos ganham um análise bem mais complexa e profunda que nas demais. E assim como Laura; Sabina, Eva e Ruzena (as amantes) funcionam para essas três mulheres, como o contraponto aos eu também perdidos e solitários nos conflitos existenciais. Os eu das amantes são assim, opostos e simultaneamente complementares visto que a exterioridade delas ressalta a difícil e angustiante peregrinação de Tereza, Markéta e Kamila, rumo a si mesmas.

Embora haja essa identificação com as mulheres dos três romances anteriores, nesse romance, Agnes é fundamentalmente o don Juan, especialmente o don Juan lírico vivido por Tomas de A lnsustentável leveza do Ser em toda a sua essência. No triângulo amoroso de $\mathbf{A}$ imortalidade composto por Agnes, Laura e Paulo, Agnes é sem dúvida o pólo irradiador dos conflitos existenciais do ser humano. Segundo Lukács (2000) o 
romance moderno trás em sua forma um indivíduo problemático que com a perda da unicidade do mundo helênico se fragmentou, se perdeu a forma romanesca narra exatamente o percurso solitário em busca desse eu perdido e fragmentado. Esse percurso é assim um espaço de autoconhecimento e de reconhecimento das alteridades da alma, porém as personagens de kundera não chegam a esse processo de autoconhecimento, ao contrário elas se perdem cada vez mais nessa busca. Agnes, digna representante da crise sem saída vivida pelo indivíduo na contemporaneidade, vai tão ao fundo nessa procura que não consegue voltar mais, chega ao extremo; a morte é sua única saída. A representação dessa perda da unicidade do sujeito é tão forte nesse romance a ponto de o próprio autor|narrador e personagem confessar ao amigo Avenarius que teria antecipado o nome do livro, já que esse seria verdadeiramente A insustentável leveza do ser.

Se em A imortalidade Kundera explora à exaustão os conflitos existências por meio, sobretudo, da personagem juanesca Agnes, em A lentidão os don Juans são representativos de mundos e épocas diferentes, eles são no romance as representações e o diálogo entre esses dois mundos: o século XVIII e o nosso.

A escolha do século XVIII é providencial para Kundera, esse é na verdade o século de Kundera. O próprio autor reverencia esse período da ficção. Para ele, esse é o momento em que a atitude libertina salta das brumas para as páginas do romance, Sade, Crébillon e Choderlos de Laclos com suas Ligações perigosas são dignos representantes desse cenário da libertinagem ficcional do século XVIII. E como representante do universo narrativo desse século, Kundera elege o conto de Vivant Denon. O autor de A lentidão parece em verdade, recriar o conto de Denon por meio da própria imaginação, transformando-o numa narrativa independente dentro da grande narrativa de A lentidão. A escolha do conto de Denon se deve segundo o narrador, pelo fato de "estar hoje em dia entre as obras literárias que parecem melhor representar a arte e o espírito do século XVIII."(Kundera, 1995:11)

A lentidão é assim, uma espécie de fábula romanesca em que Kundera cria três narrativas dentro de um grande romance. Uma ambientada no século XVIII, outra ambientada nos nossos dias, e, além dessas duas, constrói um espaço narrativo para si próprio no qual se coloca enquanto narrador, autor bem como personagem principal dessa terceira narrativa. O castelo onde se hospeda com a mulher é o cenário em que se desenrolam as três histórias desse romance: a de Madame de T.(do conto de Denon), a 
de Vincent e a do próprio autor-narrador o qual de seu quarto de hóspede, observa e acompanha toda a movimentação nesse cenário seja a do século XVIII, seja a do presente.

Ao trazer o século representativo da atitude libertina para sua narrativa, Kundera reafirma a importância dessa figura no conjunto de sua obra. E por intermédio do confronto dos don Juans do passado com os don Juans do presente, possibilita um olhar sobre esses dois mundos, bem como permite a percepção das transformações por que passou e por que passa a humanidade desde o século das luzes.

Ao contrário da impotência das imagens tirânicas de nossos dias ou da franqueza deselegante resultado da economia de tempo no presente, o mundo de Madame de T., vivencia e alimenta a potência da verdadeira libertinagem, para isso trata a conquista, o jogo do amor, como uma arte em que cada palavra, cada gesto deve ser pensado, deve ser degustado. $\mathrm{O}$ ritual de conquista desencadeado por Madame de T. exige tempo, reflexão e dedicação ao outro, algo distante de nossos dias. Segundo o narrador o encontro amoroso do mundo de Madame de T.

Não é como hoje em dia, em que uma moça pode dizer: você quer, eu também quero, não vamos perder tempo! Para eles essa franqueza mantém-se por trás de uma barreira que não pode ser transposta apesar de todas as suas convicções libertinas. (...) Madame de T. baliza o terreno, prepara a próxima fase dos acontecimentos, dá a entender a seu parceiro o que ele deve pensar e como deve agir. Faz tudo isso com finura, com elegância, e indiretamente, como se falasse de outra coisa. (Kundera, 1995, p. 37,38)

Utilizando-se da metáfora do dançarino, A lentidão nos coloca diante dos vários formatos de don Juan dos nossos dias. Embora mantenha sua postura de sedutor no universo do erotismo, don Juan, nesse romance, extrapola definitivamente e visivelmente essa ligação histórica com as conquistas amorosas, ele se efetiva enquanto um grande sedutor, um sedutor das massas. Para tanto, há que se criar e passar uma imagem, um discurso. A sedução dos dançarinos é a sedução construída na mídia, nos cenários políticos, no palco dos negócios... Para se manter centro de atenção, esses don Juans devem exercer com habilidade os passos dos dançarinos. Por isso Pontevin, um don Juan clássico, conclui que

não só é possível como provável que um verdadeiro dançarino, um Berck, um Duberques, diante de uma mulher, não sinta nenhuma vontade de se exibir ou de seduzir. Não lhe ocorreria contar a história de uma datilógrafa que ele 
arrastou pelos cabelos até sua cama porque a confundiu com outra. Pois o público que ele quer seduzir não são as mulheres concretas e visíveis, mas a grande multidão dos invisíveis (Kundera, 1995, p. 33)

Ainda segundo Pontevin, é na invisibilidade do público desses don Juans que se deve elaborar a teoria sobre o dançarino, segundo ele, "é nisso que reside a assustadora modernidade dessa personagem! Ele não se exibe diante de você ou de mim mas diante do mundo inteiro! E o que é o mundo inteiro? Um infinito sem rostos! Uma abstração!"(1995:33)

Assim em A lentidão vimos transitar num mesmo espaço vários espectros de don Juans, os quais são representativos de seu tempo e dos valores que perpassam esse tempo. Enquanto os don Juans do século XVIII degustam e saboreiam cada instante de suas conquistas, fazendo do ato de seduzir uma arte, os conquistadores do nosso tempo, tal qual os dançarinos, procuram conquistar não somente o sexo oposto, mas multidões.

Assim como aconteceu com o ato da sedução, nos nossos dias os prazeres também se modificaram. Os prazeres epicurianos cederam lugar aos prazeres conferidos pelas máquinas, pelo automóvel ou pela velocidade. Desse modo, num encontro - cuja a audácia narrativa ultrapassa qualquer idéia de verossimilhança, mas é assegurado na credibilidade conferida pelos elementos textuais - entre o cavalheiro do Século XVIII que viveu noite plena com Madame de T. e Vincent que também vivera uma noite de 'amor', porém fracassada, a narrativa coloca o leitor frente as muitas contradições desses mundos.

Assim, enquanto nosso cavalheiro do século XVIII caminha lentamente em direção a sua carruagem, numa lentidão em que se pode reconhecer uma marca de felicidade e, portanto o desejo de guardar cada detalhe na memória, o nosso cavalheiro do final do século XX, sentindo uma "sede insaciável de velocidade" (Kundera, 1995, p.156) se encaminha para sua moto, nele pode se observar o amor por sua moto, a máquina a qual o fará apagar da memória todas as frustrações desta noite, esquecer de si mesmo inclusive, visto que existe "um vínculo secreto entre a lentidão e a memória, entre a velocidade e o esquecimento.' (Kundera, 1995, p. 42)

\section{CONCLUSÃO}

Don Juan trata-se de uma figura constante na literatura desde sua aparição no século XVII com Tirso de Molina. Na obra espanhola, don Juan teve como objetivo apontar e denunciar as corrosões sócias. Nesse 
processo de desvelamento, tomou como ponto primordial a sedução, a qual irá evidenciar perante o público a fragilidade do caráter dos membros daquela sociedade, que por interesse ou por ausência de princípios, acaba por sucumbir com certa facilidade aos atrativos de don Juan.

Na peça espanhola, don Juan não teve uma configuração na realidade objetiva, configurou-se como uma entidade que criada para se revelar enquanto habitante de um mundo em transição onde os valores não são mais regidos pelas leis divinas e o indivíduo representado por don Juan é aquele que não teme as leis de Deus ao mesmo tempo em que se sente em condições de interferir e mudar, pelas próprias ações, os rumos da vida e do homem.

Ao emergir na obra de Kundera, don Juan retoma o princípio responsável por sua mitificação: a sedução generalizada. Mas os arquétipos de libertinos empreendidos por esse autor tornam-se egos experimentais na medida em que vagam solitariamente a procura de si mesmos e vivem suas experiências em um mundo em que nem Deus nem o homem existem mais como centro da história, os limites extremos da relação homem/mundo são o amor e o desejo, cuja ética é o erotismo em suas diferentes formas.

Já que os don Juans de Kundera vagam, num círculo fechado em busca de sentidos e da completude de um ser fragmentado, o mosaico múltiplo e polifônico configurado por eles revela as variações existenciais de nossa era. Por meio das experiências desses egos, revela que a identidade do eu é incompleta, que a lembrança pode significar esquecimento e a procura do eu pode representar a perda definitiva de si, como se vê em Agnes ou em Tamina. Do mesmo modo, a voz filosófica do narrador autoral assegura uma reflexão sobre o mundo e a nossa existência.

Tomando o conjunto da obra como observatório, concluímos que Milan Kundera se vale dessa personagem e de seus narradores, como forma de interligar seu pensamento no correr de sua historiografia literária. Os textos desse autor são indissociáveis, a construção de sentidos extrapola os limites impostos pelo fim técnico de uma narrativa. Isto porque a cada romance nos deparamos com uma modalidade diferente de don Juan a qual tem suas ações pensadas pela voz filosófica de seus narradores autorais. Os don Juans são responsáveis assim, por credibilizar, aos olhos do leitor, as reflexões empreendidas pela voz filosófica do narrador que se firma gradativamente no fazer literário de Milan kundera. 


\section{REFERÊNCIAS}

BARROSO, Wilton. A voz filosófica do narrador kunderiano. In: XI CONGRESSO INTERNACIONAL DA ABRALIC - Tessituras, Interações, Convergências. 2008. USP - São Paulo.

COJORIAN, Alex. "Estas são as horas minhas" In: O burlador de Sevilha e o convidado de Pedra. Trad. Alex Cojorian. Brasília, Círculo de Brasília, 2004.

GADAMER, Hans-Georg, O conceito de jogo. In. Verdade e método. Trad. Flávio Paulo Meurer. Petrópolis: Vozes, 2004.

GONZALES, Mário M. Introdução In. O burlador de Sevilha e o convidado de Pedra. Trad. Alex Cojorian. Brasília, Círculo de Brasília, 2004.

KUNDERA, Milan, Risíveis amores. Trad. Tresa Bulhões C. da Fonseca. Rio de Janeiro: Nova fronteira, 1985.

, A brincadeira. Trad. Teresa. Bulhões C. da Fonseca e Ana Lúcia Moojen Andrada. Rio de Janeiro: Nova fronteira, 1986.

A arte do romance. Trad. Teresa Bulhões C. da Fonseca e Vera Mourão. Rio de Janeiro: Nova fronteira, 1988.

A Valsa dos Adeuses. Trad. Teresa Bulhões C da Fonseca

e Anne Marie Bruno. Rio de Janeiro: Ed. Nova Fronteira, 1989.

A imortalidade. Trad. Teresa Bulhões C. da Fonseca e Anna Lúcia Moojen Andrada. Rio de Janeiro: nova Fronteira, 1990.

A vida está em outro lugar. Trad. Denise Range Barreto. Rio de Janeiro: Nova Fronteira, 1991.

- Os testamentos traídos. Trad. Teresa Bulhões C. da Fonseca e Maria Luiza N. da Silveira. Rio de Janeiro: Nova Fronteira, 1994.

A lentidão. Trad. Teresa Bulhões C. da Fonseca e Maria Luiza N. da Silveira. Rio de Janeiro: Nova Fronteira, 1995. 
A cortina. Trad. Teresa Bulhões C. da Fonseca. São Paulo: Companhia das letras, 2006.

A ignorância. Trad. Teresa Bulhões C. da Fonseca. São Paulo: Companhia das Letras, 1989.

O livro do Riso de do esquecimento. Trad. Teresa Bulões C. da Fonseca. São Paulo: Licença editorial para o Círculo do Livro por cortesia da Editora Nova Fronteira.

A insustentável leveza do ser.Trad. Teresa Bulhões C. da Fonseca. Direitos de edição da obra em Língua Portuguesa da Ed. Nova Fronteira, cedidos à Ed. Record de Serviços de Imprensa S.A. RJ. 1995.

LUKÁCS, Georg, A teoria do romance: um ensaio histórico-filosófico sobre as formas da grande épica. Trad. José Marcos Mariani de Macedo. São Paulo: Duas Cidades, Ed. 34, 2000.

MAFESOLI, Michel, A conquista do presente.Trad. Alípio de Sousa Filho. Natal (RN): Argos, 2001.

MOLINA, Tirso de, O burlador de Sevilha e o convidado de Pedra. Trad. Alex Cojorian. Brasília, Círculo de Brasília, 2004.

RIBEIRO, Renato Janine, A sedução e suas máscaras: ensaios sobre Don Juan. São Paulo, Schwarcz Ltda, 1988. 